\title{
Informação e consulta nas multinacionais: A experiência de representantes portugueses em Conselhos de Empresa Europeus
}

Information and consultation in multinationals: The experience of Portuguese representatives in European Works Councils Information et consultation au sujet des multinationales. L'expérience des représentants portugais dans les Conseils d'Entreprise Européens

Hermes Augusto Costa e Pedro Araújo

\section{OpenEdition}

\section{Journals}

Edição electrónica

URL: http://journals.openedition.org/rccs/722

DOI: $10.4000 /$ rccs.722

ISSN: $2182-7435$

\section{Editora}

Centro de Estudos Sociais da Universidade de Coimbra

Edição impressa

Data de publição: 1 Dezembro 2007

Paginação: 3-33

ISSN: 0254-1106

Refêrencia eletrónica

Hermes Augusto Costa e Pedro Araújo, «Informação e consulta nas multinacionais: A experiência de representantes portugueses em Conselhos de Empresa Europeus », Revista Crítica de Ciências Sociais [Online], 79 | 2007, colocado online no dia 01 outubro 2012, criado a 19 abril 2019. URL : http:// journals.openedition.org/rccs/722; DOI : 10.4000/rccs.722 


\section{Informação e consulta nas multinacionais: A experiência de representantes portugueses em Conselhos de Empresa Europeus'}

A partir da experiência de representantes portugueses em Conselhos de Empresa Europeus (CEE), aborda-se a avaliação que aqueles fazem do cumprimento dos dois princípios basilares da Directiva: a informação e a consulta. A este propósito, são tidas em conta duas dimensões da vida dos CEE: a dimensão funcional e a dimensão das possibilidades práticas. A primeira reporta-se ao modo como a informação e a consulta se encontram vertidas nos textos dos acordos que ditam o modus operandi dos CEE e ao modo como os representantes dos trabalhadores avaliam a informação que lhes é transmitida. A segunda dimensão encontra-se mais orientada para o princípio da consulta e para as possibilidades de os CEE condicionarem as decisões das multinacionais. Ainda que ambas as dimensões sejam olhadas como pouco entusiasmo pelos representantes portugueses, este texto, apoiando-se no exemplo da GM-Europa, não deixa, todavia, de fazer referência ao papel que os CEE podem desempenhar na construção de uma identidade laboral transnacional.

\section{Introdução}

A construção de uma identidade laboral transnacional vem sendo reclamada há décadas por trabalhadores e sindicatos no contexto da União Europeia. A ideia de um "Modelo Social Europeu" - condizente, entre outros pontos, com elevados índices de protecção social, o reconhecimento dos direitos laborais, a valorização da negociação colectiva enquanto elemento regulador das relações de trabalho, ou da maximização de serviços públicos de qualidade - fez, de resto, igualmente jus a um projecto de "Europa Social”. $\mathrm{Na}$ prática, porém, é sabido que o modelo social europeu não foi sinónimo de Europa integrada, em virtude da coexistência de uma diversidade de

\footnotetext{
${ }^{1}$ Este trabalho é parte de uma ampla investigação realizada, entre Junho de 2005 e Outubro de 2007, ao abrigo do projecto "Os Conselhos de Empresa Europeus: entre a responsabilidade social da empresa e a participação laboral” (POCI/SOC/59689/2004), financiado pela Fundação para a Ciência e a Tecnologia.
} 
sistemas de relações laborais e regimes de protecção social que, consequentemente, suscitaram a identificação de cenários-tipo (igualmente diferenciados) para o futuro da Europa Social.

Ainda que possa ser problemático falar num sistema europeu de relações laborais, convirá, todavia, recordar alguns momentos importantes que ajudaram a dar corpo à ideia de Europa Social (Costa, 2005: 249-256):

- o Tratado de Roma (1957), que, lançou as bases de uma política social europeia;

- o Comité Económico e Social (1957), que acolhe os parceiros sociais tradicionais (patrões e sindicatos), bem como diversos grupos de interesses da Comunidade;

- o Acto Único Europeu (1987), que consagrou o conceito de "mercado interno", acrescentando ao Tratado de Roma disposições relativas à melhoria do ambiente no meio de trabalho, ao diálogo social e à coesão económica e social;

- a Carta Comunitária dos Direitos Sociais Fundamentais dos Trabalhadores (1989), que veio consagrar, no plano comunitário, um conjunto de princípios aplicáveis à protecção dos trabalhadores e estabelecer os grandes princípios em que se baseia o modelo europeu de direito do trabalho;

- o Tratado de Maastricht (1992), que abriu caminho para um maior aprofundamento e integração da então Comunidade Europeia e que incidiu tanto na consolidação dos direitos sociais fundamentais dos trabalhadores (na forma como eles estavam expressos na Carta Comunitária), como no desenvolvimento de acções em domínios como a exclusão social, os deficientes, a pobreza ou a integração dos migrantes de "países terceiros";

- o Protocolo a Doze, que autorizou um Acordo a Onze sobre a Política Social e que ampliou as competências legais de intervenção no domínio da política social da UE, permitiu um maior espaço para a votação por maioria qualificada e reforçou do papel dos "parceiros sociais" europeus, reconhecendo-lhes a possibilidade de negociarem acordos colectivos europeus (de que são exemplo os acordos-quadro sobre licença parental, 1995, trabalho a tempo parcial, 1997, e contratos de duração determinada, 1999, ou ainda acordos celebrados numa base voluntária, como os relativos ao teletrabalho, 2002, ao stress associado ao trabalho, 2004, ou à perseguição e violência no trabalho, 2007);

- a Directiva 94/45/CE que, em 1994, instituiu os Conselhos de Empresa Europeus (CEE), destinados a instituir mecanismos de informação e consulta dos trabalhadores nas empresas ou grupos de empresa de dimensão comunitária; 
- o Tratado de Amesterdão (1997), que, entre outros pontos, veio: recuperar o texto do Acordo sobre a política social do Tratado de Maastricht, integrando-o no articulado do novo tratado; definir os objectivos da UE no domínio da política social, fazendo explicitamente referência à Carta Comunitária dos Direitos Sociais Fundamentais dos Trabalhadores, de 1989; fixar as matérias sociais que carecem de aprovação por maioria qualificada; definir as condições de intervenção dos parceiros sociais nos processos de decisão da Comunidade no domínio social; incluir um "capítulo sobre o emprego", onde se reafirma que a responsabilidade primeira no domínio do emprego cabe aos Estados-membros, embora estes passem a inscrevê-la doravante no quadro de uma estratégia coordenada no âmbito da Comunidade;

- a Carta dos Direitos Fundamentais da UE (no quadro da Cimeira Europeia de Nice, em Dezembro de 2000), que abriu também um novo capítulo na implementação legal dos direitos sindicais nos níveis nacional e transnacional e se configurou como um catalisador da construção de um sistema europeu de relações laborais.

Neste texto, o nosso olhar vai para uma dessas "peças" de legislação europeia que criou condições para um reforço da informação e consulta dos trabalhadores nas empresas/grupos de empresas de dimensão comunitária - através da constituição de Conselhos de Empresa Europeus (CEE) ou de procedimentos de informação e consulta dos trabalhadores (PIC) -, por via da acima referida Directiva 94/45/CE, de 22.09.1994. O relativo atraso da transposição da Directiva para o ordenamento jurídico português ${ }^{2}$ e o facto de o tecido produtivo português ser composto essencialmente por pequenas e médias empresas colocaram, à partida, um conjunto de obstáculos à constituição de CEE e, portanto, à participação laboral naquelas instâncias transnacionais. ${ }^{3}$ Para analisarmos o modo como a eficiência e eficácia da Directiva são perspectivadas, centrámos a nossa atenção sobretudo nas experiências de representantes de trabalhadores portugueses em CEE de filiais de empresas estrangeiras.

Na primeira parte deste artigo, procedemos a uma breve síntese dos propósitos inerentes à Directiva 94/45/CE e abordamos sucintamente os procedimentos metodológicos subjacentes à pesquisa. Na segunda parte, prestamos atenção ao modo como as noções de informação e consulta são acolhidas pelos representantes portugueses em CEE, bem como às práticas

\footnotetext{
${ }^{2}$ Que só ocorreu em 1999, através da Lei 40/99, de 9 de Junho de 1999, posteriormente transposta para o Código do Trabalho, artigos $471 .^{\circ}$ a $474 .^{\circ}$, e para a Lei 35/2004 (artigos 365. ${ }^{\circ}$ a $395 .^{\circ}$ ).

${ }^{3}$ Uma análise desses obstáculos tendo por referência a realidade portuguesa pode encontrar-se em Costa (2004, 2006) e Costa e Araújo (2006, 2007a, 2008).
} 
de informação e consulta em sede dos CEE. A análise incide aqui sobre a avaliação da dimensão funcional dos CEE por parte dos representantes portugueses. Em seguida, tendo ainda por base a experiência dos representantes portugueses, procura-se apurar em que medida os CEE são instrumentos geradores de eficácia, ou seja, saber se se configuram como estruturas capazes, por exemplo, de condicionar decisões das administrações das empresas, evitando-as, protelando-as ou alterando-as. Aborda-se, nesse sentido, outra dimensão complementar à dimensão funcional dos CEE que se prende, desta feita, com as suas possibilidades práticas, isto é, com a possibilidade de se poderem alcançar resultados favoráveis aos trabalhadores por intermédio dos CEE. Em contraponto à visão pouco optimista dos representantes portugueses, patente em ambas as dimensões aqui objecto de análise, na quarta parte do artigo recuperamos alguns "sinais de esperança", isto é, sinais reveladores de que há um "mundo a ganhar" (Marx e Engels, 1982: 136) para os trabalhadores em resultado da sua participação nos CEE.

\section{Os propósitos da Directiva e as opções da investigação}

A emergência da Directiva 94/45/CE (de 22.09.1994) - que tornou possível a constituição de CEE ou PIC - insere-se numa luta que há muito vinha sendo travada no contexto europeu no sentido de fazer corresponder à crescente operação das empresas à escala transnacional mecanismos de representação e participação dos trabalhadores adequados a essa escala. Isto é, expandindo-se a esfera de acção das multinacionais, era imperativo que se expandisse também a esfera de actuação dos trabalhadores. Simples na sua formulação, o processo de criação desses mecanismos revelar-se-ia longo, complexo e até controverso. ${ }^{4}$ Ainda que, para alguns, a adopção da Directiva 94/45/CE tivesse redundado numa versão fragilizada das propostas até então apresentadas sobre informação e consulta dos trabalhadores (Leite et al., 1996), esta representa um importante instrumento jurídico tendente ao reforço da representação e participação laboral no âmbito das multinacionais, representação e participação que os sindicatos, particularmente em Portugal, nunca lograram verdadeiramente maximizar (Costa, 2005). A emergência da Directiva suscitou, assim, um conjunto de expectativas, nomeadamente quanto ao reforço da europeização do diálogo social (Paternotre, 1998), ao incremento da democracia laboral (Buschak, 1995), ao estabelecimento de redes de comunicação entre representantes dos trabalhadores e estruturas de representação (Wills, 2000) e a um renovado

\footnotetext{
${ }^{4}$ Para uma análise dos antecedentes da Directiva 94/45/CE, cf. Costa (2005: 607-610).
} 
fôlego para a acção sindical e para a reivindicação colectiva (Lecher et al., 1999; Wills, 2004; Telljohann, 2005). Em última análise, almeja-se, como referíamos acima, a construção de uma identidade laboral europeia (Whittall, Knudsen e Huijgen, 2007).

O objectivo principal da Directiva é "melhorar o direito à informação e consulta dos trabalhadores nas empresas ou grupos de empresas de dimensão comunitária" (n. ${ }^{\circ} 1$ do art. ${ }^{\circ} 1 .^{\circ}$ ). ${ }^{5}$ As oportunidades emergentes oferecidas pela Directiva englobam, deste modo, a concessão de direitos de informação - sobre "questões transnacionais susceptíveis de afectar consideravelmente os interesses dos trabalhadores" (art. ${ }^{\circ} 6 .^{\circ}$, n. $\left.^{\circ} 3\right)$ - e direitos de consulta - a "troca de opiniões e o estabelecimento de um diálogo entre os representantes dos trabalhadores e a direcção central ou qualquer outro nível de direcção mais apropriado" [art. ${ }^{\circ} 2 .^{\circ}, \mathrm{n} .^{\circ} 1$, al. f)].

Como já referimos, a Directiva 94/45/CE consagra dois mecanismos de informação e consulta dos trabalhadores nas empresas/grupos de empresas de dimensão comunitária: os CEE ou os PIC. Uma vez aberto o processo negocial $^{6}$, o passo seguinte consiste na formação de um Grupo Especial de Negociação (GEN) (art ..$^{\circ}$ ) composto por representantes dos trabalhadores [art. $.^{\circ},{ }^{\circ} .^{\circ} 2$, al. b)]. Cabe aos Estados-membros determinar o modo de eleição ou de designação dos membros do GEN que devem ser eleitos ou nomeado no seu território [art. $5 .^{\circ}$, n. $^{\circ} 2$, a)]. Porém, nas eleições ou nomeações deve assegurar-se: a) a existência de um representante por cada Estado-membro no qual a empresa de dimensão comunitária possua a empresa que exerce o controlo ou uma ou mais empresas controladas; b) a existência de representantes suplementares em número proporcional ao dos trabalhadores dos estabelecimentos, da empresa que exerce o controlo ou das empresas controladas nos termos da legislação do Estado-membro em cujo território se situa a direcção central (art. 5. ${ }^{\circ}$, n. $\left.^{\circ} 2\right)$. A direcção central e direcções locais são, posteriormente, informadas da composição do GEN [art. 5. ${ }^{\circ}$, n. ${ }^{\circ} 2$, d)].

\footnotetext{
${ }^{5}$ A "empresa de dimensão comunitária" é aquela que emprega mil ou mais trabalhadores nos Estados-membros e que em pelo menos dois Estados-membros diferentes emprega um mínimo de cento e cinquenta trabalhadores em cada um deles $\left[\operatorname{art}^{\circ}{ }^{\circ} 2 .^{\circ}\right.$, n. ${ }^{\circ} 1$. al. a)]. Por sua vez, o "grupo de empresas de dimensão comunitária" é aquele que emprega pelo menos mil trabalhadores nos Estados-membros, que possui, no mínimo, duas empresas membros do grupo em Estados-membros diferentes, sendo que cada uma dessas duas empresas deve empregar, no mínimo, cento e cinquenta trabalhadores [art. ${ }^{\circ} 2 .^{\circ}$, n. $^{\circ} 1$., al. c) ].

${ }^{6}$ A abertura do processo negocial para a instituição de um CEE ou de um PIC pode ser desencadeada: a) por proposta, oral ou escrita, da direcção central ou b) por requerimento dos trabalhadores, este último, "mediante pedido escrito de, no mínimo, 100 trabalhadores, ou dos seus representantes, provenientes de pelo menos duas empresas ou estabelecimentos situados em pelo menos dois Estados-membros diferentes" (art. 5. $\left..^{\circ}, .^{\circ} 1\right)$.
} 
Posteriormente, deve adoptar-se um dos mecanismos de informação e consulta (CEE ou PIC) e celebrar-se o respectivo acordo (art. 6..$^{\circ}$. Cabe, deste modo, ao GEN fixar, em colaboração com a direcção central e mediante acordo escrito, o âmbito de acção, a composição, as atribuições e a duração do mandato dos CEE ou as regras de execução dos PIC (art. . $^{\circ}$, n. $^{\circ}$ 3). O acordo escrito funciona, pois, como uma espécie de guia que condicionará a actividade futura dos CEE. Ainda assim, o facto de a diversidade de experiências constituir uma das características mais salientes do funcionamento dos CEE (Hyman, 2000; Kerckhofs, 2003; Waddington, 2003) permite argumentar que as dinâmicas dos CEE são mais bem observáveis na prática. É por esse facto também que, sem descurar a importância de analisar o registo formal dos CEE (Costa e Araújo, 2007b), se deve atentar igualmente num registo qualitativo, que se prende mais directamente com as avaliações que os representantes dos trabalhadores eleitos/nomeados para os CEE fazem da sua experiência de participação nessas instâncias. É também esse registo que privilegiamos neste texto.

A European Works Councils Database do European Trade Union Institute for Research, Education, Health and Safety (ETUI-REHS), elaborada sob a coordenação de P. Kerckhofs e I. Pas (2006), assinala 2.204 multinacionais abrangidas pela Directiva, das quais 772 (35\%) possuem CEE. A este ritmo, sendo em média criados cerca de 30 a 40 novos CEE por ano, serão necessários cerca de 35 anos para ver um CEE instalado em todas as multinacionais actualmente abrangidas pela Directiva (Kerckhofs, 2006: 47). A expressão quantitativa dos CEE - o número de CEE estabelecidos frente ao número de multinacionais em condições de os constituir - sugere, pois, claramente que a Directiva tem ainda um longo caminho a percorrer. Embora o maior ou menor sucesso da aplicação da Directiva constitua um elemento importante da análise dos CEE, não será, ainda assim, o mais relevante. Mais importantes, em nossa opinião, são as dinâmicas institucionais e colectivas que, por seu intermédio, estão a emergir, bem como a capacidade diferencial dos CEE para cumprirem as expectativas que lhe estão associadas.

É incontornável, no entanto, que retenhamos alguns dados sobre a realidade portuguesa. Assim sendo, para Portugal, constatamos que a European Works Councils Database (2006) recenseia 615 multinacionais como estando abrangidas pela Directiva, das quais 335 (mais de 50\%, portanto) constituíram 343 CEE com base em 482 acordos. Esta descoincidência entre o número de multinacionais (335) que constituíram CEE, o número de CEE efectivamente existentes (343) e o número de acordos em vigor (482) resulta do facto de algumas multinacionais poderem constituir mais do que um CEE na base de mais do que um acordo. A diferença entre o número de 
CEE e o número de acordos justifica-se, ainda, pelo facto de novos acordos serem firmados depois de fusões ou dissoluções de empresas ou devido à renegociação de alguns acordos.

Mas se atentarmos no número de representantes portugueses eleitos ou nomeados para os CEE teremos uma visão mais aproximada da participação laboral portuguesa nos CEE. Assim sendo, na investigação realizada (Costa e Araújo, 2007c), foram identificados 201 representantes portugueses em CEE. ${ }^{7}$ Estamos, no entanto, conscientes de que o universo das multinacionais é extremamente instável, pelo que não é líquido que aquele número de representantes portugueses não possa sofrer alterações. ${ }^{8}$

Cerca de 20\% dos 201 representantes de trabalhadores portugueses em CEE (mais precisamente 37 representantes) foram entrevistados segundo um critério de distribuição proporcional à sua representatividade sectorial ${ }^{9}$. $\mathrm{Na}$ condução das entrevistas foram privilegiados três grupos de questões. Um primeiro, relativo ao processo de instituição dos CEE, que abarca aspectos como a iniciativa para a constituição dos CEE, a participação de representantes portugueses na negociação dos acordos, a avaliação do conteúdo dos acordos, entre outros pontos. Um segundo grupo, que incide sobre o modus operandi dos CEE. Aqui, os representantes foram confrontados com questões como a sua participação nas reuniões dos CEE (preparatórias, ordinárias, posteriores e extraordinárias), as questões e os problemas mais recorrentemente levantados pelos representantes, a avaliação dos resultados das reuniões (a quantidade, qualidade e oportunidade da informação, a consulta, e o princípio da confidencialidade), a restituição da informação

\footnotetext{
7 Os 201 representantes portugueses foram identificados a partir dos acordos de CEE constantes das bases de dados de 2004 e 2006 (Kerckhofs e Pas, 2004, 2006). Foram excluídos os casos em que as bases de dados, bem como os textos dos acordos são omissos relativamente aos representantes portugueses. Por sua vez, no caso de revisões ou reformulações dos acordos, reteve-se o número de representantes constante do acordo mais recente.

${ }^{8}$ De facto, não só existem empresas/grupos com representantes portugueses que não aparecem referidos na European Works Council Database de 2006 ou aparecem com outra designação (a Transdev, do sector dos transportes, por exemplo, que aparece mencionada com a designação de C3-D, Caisse des Dépôts Développement), como há empresas/grupos que cessaram as suas operações em Portugal e, como tal, perderam representantes nos respectivos CEE: a Clarks, do sector do calçado, que encerrou em 2003; a Honeywell, do sector metalúrgico, que encerrou em 2005, ou a General Motors (Opel), do sector metalúrgico (automóvel), que encerrou em 2006, são apenas alguns exemplos dessa situação.

9 A distribuição dos representantes portugueses pelos sectores de actividade é a seguinte: o sector metalúrgico acolhe 63 representantes, o sector químico 37 representantes, as actividades financeiras 30 representantes (assinale-se, no entanto, que este número se encontra inflacionado pelos 10 representantes portugueses do único CEE constituído numa multinacional portuguesa: o CEE do Grupo BES), a indústria alimentar e hotelaria 27 representantes, e o sector têxtil 13 representantes. Tendo em conta esta distribuição sectorial, e apenas fazendo referência aos 5 sectores mais representativos, foram entrevistados 12 representantes do sector metalúrgico, 7 do sector químico, 6 das actividades financeiras, 5 da indústria alimentar e hotelaria e 3 do sector têxtil.
} 
e dos resultados das reuniões aos trabalhadores, e a consolidação de redes informais entre representantes dos trabalhadores para além dos espaços de reunião formal. Por fim, um terceiro grupo de questões orientou-se sobretudo para uma avaliação global dos CEE, designadamente das suas principais potencialidades, limitações e impactos locais e transnacionais. ${ }^{10}$

\section{A dimensão funcional dos Conselhos de Empresa Europeus}

Um dos tópicos que mais espaço tem ocupado nos debates em torno dos CEE diz respeito à dimensão funcional destas instâncias (Béthoux, 2004), ou seja, à concretização do duplo objectivo subjacente à Directiva e aos CEE: a informação e consulta transnacionais dos trabalhadores. Em termos gerais, a informação levanta questões que gravitam em torno de três vectores principais: a quantidade de informação, a qualidade de informação e a oportunidade da informação. Por sua vez, a questão da consulta não se faz sem ter em conta, por um lado, esses mesmos três vectores da informação e, por outro, a capacidade dos CEE para influenciar decisões, enquanto expressão de uma outra dimensão dos CEE que abordaremos na secção seguinte: as possibilidades práticas dos CEE (Didry et al., 2005: 37). A dimensão funcional não pode, por isso, dissociar-se de todo da dimensão das possibilidades práticas.

Em termos processuais, as regras segundo as quais os representantes dos trabalhadores têm o direito de se reunir para proceder a uma troca de opiniões sobre as informações que lhes são comunicadas ficam determinadas nos acordos. A Directiva estabelece, porém, alguns requisitos básicos. Assim, os CEE têm o direito de se reunir com a direcção central uma vez por ano de modo a que os trabalhadores possam ser informados e consultados, com base num relatório elaborado pela direcção central, sobre a evolução das actividades da empresa ou grupo de empresas de dimensão comunitária e sobre as suas perspectivas. A reunião deve incidir sobre um conjunto de pontos que se encontram previstos no anexo 2 da Directiva:

- a estrutura da empresa;

- a situação económica e financeira;

- a evolução provável das actividades, produção e vendas;

- a situação e evolução provável do emprego;

- os investimentos;

\footnotetext{
${ }^{10}$ As entrevistas semi-estruturadas com os representantes portugueses em CEE foram todas realizadas entre Setembro de 2006 e Fevereiro de 2007, ainda que, ao longo da investigação, tenhamos realizado outras entrevistas com líderes sindicais e investigadores estrangeiros estudiosos do tema dos CEE. Além disso, entre Março e Abril de 2007, aplicámos ainda um inquérito (via correio e e-mail) aos representantes portugueses em CEE, o qual se destinou a complementar e consolidar os tópicos das entrevistas (Costa e Araújo, 2007c: 157-211,323-334), embora não seja objecto de tratamento específico neste artigo.
} 
- as alterações de fundo relativas à organização;

- a introdução de novos métodos de trabalho ou de novos processos de produção;

- as transferências de produção;

- as fusões, a redução da dimensão ou encerramento de empresas, de estabelecimentos ou de partes importantes de estabelecimentos;

- os despedimentos colectivos.

Tendo em conta esse requisitos, os acordos negociados com base no artigo 6. ${ }^{\circ}$, ou seja, depois da entrada em vigor da Directiva a 22 de Setembro de $1996^{11}$, estabelecem os modos de funcionamento dos CEE, incluindo as empresas do grupo de empresas de dimensão comunitária ou os estabelecimentos da empresa de dimensão comunitária abrangidos pelo acordo [art. 6. ${ }^{\circ}$, n. $^{\circ}$ 2, al. a)]; a composição do CEE, bem como o número de membros, a distribuição dos lugares e a duração do mandato [art. $6^{\circ}{ }^{\circ}$, n. $^{\circ} 2$, al. b)] (as partes possuem aqui discricionariedade total para escolher os membros e respectivo número; definir se o CEE é composto apenas por trabalhadores da multinacional ou incluir outros representantes como sejam peritos ou representantes de organizações sindicais); as atribuições e o procedimento de informação e consulta do CEE [art. $6 .^{\circ}$, n. $^{\circ}{ }^{2}$, al. c)]; o local, a frequência e a duração das reuniões do $\operatorname{CEE}\left[\operatorname{art} .6 .^{\circ},{ }^{\circ} .^{\circ} 2\right.$, al. d)]; os recursos financeiros e materiais a afectar ao CEE [art. $6 .^{\circ},{ }^{\circ} .^{\circ} 2$, al. e)]; e a duração do acordo e o seu processo de renegociação [art. $6 .^{\circ}$, n. $^{\circ} 2$, al. f)].

Embora alguns investigadores sustentem a existência de uma relação directa entre as prescrições negociadas num acordo e as práticas que se desenvolvem subsequentemente (Marginson et al., 1998; Carley e Marginson, 2000; Gilman e Marginson, 2004), para outros, a letra dos acordos e as dinâmicas de que os CEE são portadores não são necessariamente coincidentes (Waddington, 2003; Wills, 2004; Telljhoann, 2005). Concordando com esta posição, parece-nos, desde logo, curial olhar para o modo como decorrem as reuniões dos CEE, pois estas reuniões - tenham elas lugar uma ou mais vezes por ano e incidam sobre um leque mais restrito ou mais extenso de questões - constituem momentos essenciais da vida dos CEE.

As reuniões dos CEE organizam-se da seguinte forma: regra geral, têm lugar uma vez por ano - reunião anual ou ordinária - em local a definir pelas partes; a reunião anual pode ser antecedida de uma reunião onde se encontram presentes apenas os representantes dos trabalhadores; a agenda da reunião anual é definida em articulação entre a administração e os repre-

${ }_{11}$ Os acordos negociados antes da entrada em vigor da Directiva, designados de voluntários ou de antecipação à Directiva, são reconhecidos pela Directiva nos termos do seu artigo 13. . 
sentantes dos trabalhadores organizados num conselho restrito; as reuniões têm uma duração que varia entre meio dia e dois dias e realizam-se com base numa agenda previamente definida.

As reuniões preparatórias constituem uma prática na grande maioria dos CEE nos quais participam representantes portugueses, sendo consideradas por estes como extremamente importantes. Estas reuniões servem, desde logo, para fazer o levantamento de um conjunto de problemas comuns a colocar às administrações e, como tal, permitem definir uma agenda e uma estratégia, por assim dizer, paralelas às das administrações:

Na reunião preparatória é decidido que problemas colocar às direcções dos recursos humanos, visto que os directores vão estar todos presentes no dia a seguir. [...] Os [problemas] mais complicados ficam logo [na agenda]. Depois tenta-se fazer um apanhado daqueles que são comuns a toda a gente e no fim pergunta-se se alguém quer ver outro qualquer problema colocado e acrescenta-se. (Representante dos trabalhadores do CEE da Autoeuropa, 17.11.2006)

É ainda durante as reuniões preparatórias que os representantes expõem, de forma aberta e transparente, os problemas das empresas locais, independentemente de estes virem ou não a ser abordados na reunião formal com a administração. Enquanto espaço de partilha de informação sobre as realidades locais, as reuniões preparatórias são, de resto, em muitos casos, consideradas como mais frutíferas do que as reuniões ordinárias. Nas reuniões preparatórias, reforça-se o sentimento de pertença colectiva a um "corpo empresarial" comum. Mesmo que a intensidade e o tipo de problemas sejam variáveis, harmonizam-se posições entre os membros dos CEE e ensaiam-se alianças para o caso de serem apresentados problemas que digam respeito não ao Grupo, mas a sucursais particulares.

Ainda que percepcionadas pelos representantes portugueses como relativamente menos importantes do que as reuniões preparatórias, as reuniões ordinárias representam um momento de encontro entre administração e os representantes dos trabalhadores, com resultados que podem ser variados. O desencanto com as reuniões ordinárias será, no entanto, tanto maior quanto mais as reuniões se cingirem à sua execução formal, ou seja, à discussão exclusiva de questões de âmbito transnacional e à difusão de informação excessivamente generalista e técnica:

Nessas reuniões [preparatórias], estamos à vontade. Só que, lá está, depois não há seguimento. Nessas reuniões falamos de tudo e as coisas deixam de ser transnacionais, cada um fala dos problemas da sua fábrica. Mas depois, no dia seguinte, a maior 
parte dos problemas nem chegam a ser levantados porque não têm cabimento na agenda. Cada um fica a saber o que é que se passa na casa dos outros, mas na reunião com a administração a maior parte dos problemas não chega a ser abordada. E quando é, vem logo a questão do transnacional. [...] Na reunião preparatória, que é a melhor reunião, falamos de tudo o que temos a falar. E trazemos muita informação sobre a forma de trabalhar dos outros, regalias, direitos, etc. [...] A reunião preparatória é mais útil do que a reunião com a administração. A administração é: "quero, posso e mando" e os CEE não têm poder reivindicativo e interventivo. (Representante dos trabalhadores do CEE da Tenneco, 23.01.2007)

Qual o balanço global que fazem os representantes portugueses das reuniões dos CEE? Os representantes portugueses apontam, desde logo, dois factores de carácter organizacional que à partida limitam a possibilidade de melhorar o direito de informação e consulta: por um lado, a periodicidade das reuniões, sobretudo quando estas se realizam apenas uma única vez por ano; por outro lado, o tempo das reuniões, quando estas se limitam a um único dia:

Claro que todos temos noção de que o tempo é pouco e que está todo preenchido. Nas reuniões, pelo menos na reunião preparatória, a opinião é que as reuniões deveriam ter pelo menos mais um dia. Isso era importante para as pessoas se conhecerem, para criarem laços, trocarem experiências. (Representante dos trabalhadores do CEE da Saint-Gobain, 21.12.2006)

Relativamente à quantidade, qualidade e importância da informação, a posição dos representantes portugueses oscila entre uma avaliação positiva, na medida em que ela faculta uma visão global das actividades e dos problemas da multinacional até aí inacessível, e uma avaliação de pendor mais negativo, talvez mais generalizada apesar de tudo, sustentada no carácter excessivamente técnico da informação e na sua fraca relevância prática. Um défice qualitativo de informação ao qual se adiciona, portanto, um excesso quantitativo de informação técnica:

A principal ideia é que os CEE são úteis pelo leque de informações que proporcionam. Agora, é preciso ter consciência das suas funções e dos objectivos do CEE. É preciso saber filtrar o que é informação e o que é, passe a expressão, "banha da cobra”, que está tudo bem, que isto é tudo um mar de rosas, etc. [...] É verdade que, por vezes, a informação é quase nula. Há reuniões em que só se fala desta ou daquela unidade que está com problemas e fica pouco tempo para tratar do resto. Quando é assim, há pouca informação nacional para devolver aos trabalhadores. 
[...] A Federação tem economistas, advogados, etc., que nos ajudam a perceber os documentos [provenientes do CEE]. Eu acho que isso é importante e, neste sentido, os CEE são importantes. (Representante dos trabalhadores do CEE da Renault, 18.12.2006)

A principal crítica dos representantes portugueses prende-se, no entanto, com o défice de informação relativa às filiais nacionais. Orientados que estão por objectivos locais, os representantes portugueses avaliam a informação divulgada nos CEE como insuficiente:

A questão é: "vai haver despedimentos ou vai encerrar algum serviço em Portugal?" E a resposta que nos dão é: "as questões que são colocadas aqui são de âmbito geral e não de âmbito nacional". Ou seja, isto é um pouco caricato porque assim os representantes locais não vão lá fazer nada. Se é para comunicar a estratégia da empresa a nível do Grupo, então basta que comuniquem isso ao representante espanhol, por exemplo, que ele depois transmite. Porque é uma estratégia global... (Representante dos trabalhadores do CEE do Grupo Santander, 25.01.2007)

A diferença é esta: a informação que eu tenho no CEE é relativa ao Grupo e cá é relativa a Portugal. (Representante dos trabalhadores do CEE do BBVA, 26.01.2007)

Resumindo, do ponto de vista dos representantes portugueses, os CEE são efectivamente portadores de mais-valias: o acesso à informação, uma melhor percepção das actividades da multinacional, um conhecimento mais aprofundado dos problemas que afectam as multinacionais, a possibilidade de prever problemas através do conhecimento e partilha de experiências de outras sucursais, etc. Estas mais-valias encontram-se, porém, fortemente limitadas pelo défice de informação de nível local, pela qualidade da informação e, mais importante, pela incapacidade para influenciar ou alterar decisões tomadas pelas multinacionais, o que esvazia de conteúdo prático o princípio da consulta. É deste aspecto, em particular, que trataremos de seguida.

\section{As possibilidades práticas dos Conselhos de Empresa Europeus}

A abordagem da questão da consulta não se faz sem ter em consideração, por um lado, a questão da oportunidade da informação (expressão, ainda, da dimensão funcional dos CEE abordada na secção anterior) e, por outro, a questão da capacidade dos CEE para influenciarem decisões das administrações (expressão, esta sim, das possibilidades práticas dos CEE). Isto significa que o processo de tomada de decisão estaria condicionado quer 
pelo modo oportuno com as informações seriam prestadas aos trabalhadores, quer pela existência de uma consulta efectiva aos trabalhadores sobre os planos e actividades da empresa e, portanto, por uma capacidade para influenciar decisões empresarias em resultado de uma articulação entre informação, consulta e capacidade de influência. Ou seja, na sua "versão dourada", o triângulo ditaria uma influência recíproca entre os seus vértices, significando isso que o processo de tomada de decisões colheria contributos não só das administrações mas também dos representantes de trabalhadores (Fig. 1).

FIGURA 1 - Oportunidade da informação, efectividade da consulta e capacidade de influência

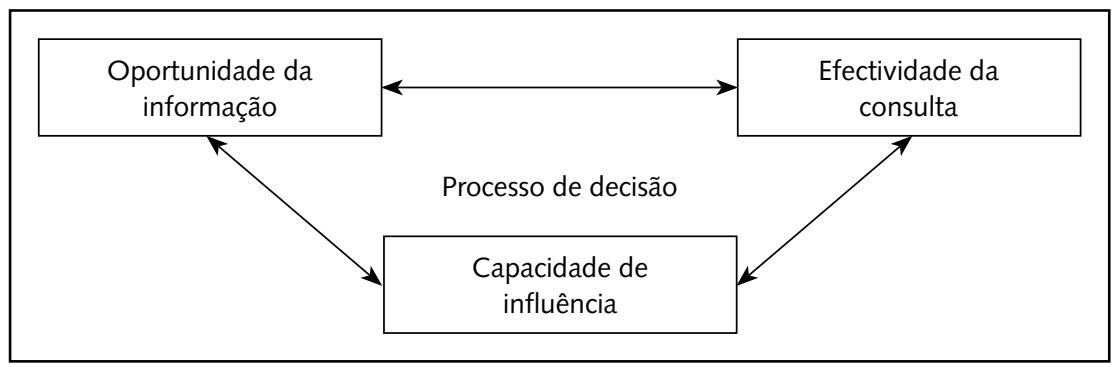

Todavia, a possibilidade de os representantes dos trabalhadores influenciarem de forma efectiva as decisões das administrações não se encontra vertida de forma explícita na Directiva, já que a definição da consulta é extremamente vaga: "a troca de opiniões e o estabelecimento de um diálogo entre os representantes dos trabalhadores e a direcção central ou qualquer outro nível de direcção mais apropriado" [art. ${ }^{\circ} 2 .^{\circ}$, al. f)]. Ainda assim, registe-se que desde há muito tempo a Confederação Europeia de Sindicatos (CES) veio pressionando a Comissão Europeia para que fosse cumprida a revisão da Directiva, prevista no texto original para 22 de Setembro de 1999. A encabeçar os aspectos sobre os quais a revisão deveria incidir aparece a definição mais clara dos termos basilares da Directiva, informação e consulta, quer quanto ao seu conteúdo, quer quanto aos modos de exercício desses direitos (EIRR, 2004: 15-16). ${ }^{12}$

\footnotetext{
${ }^{12}$ Em boa verdade, a revisão da Directiva não aparece nos discursos dos representantes portugueses de forma sistemática. É por confronto entre aquilo que são os CEE e aquilo que poderiam ser que emergem alguns aspectos que fazem parte das reivindicações associadas à revisão da Directiva entre os quais destacamos: a redução do limiar de trabalhadores para a abrangência da Directiva de 1.000 para 500 no EEE e de 150 para 100 em pelo menos dois Estados-membros; a clarificação da noção de "confidencialidade"; a garantia de participação de um representante das federações sindicais sectoriais quer nos GEN, quer nos CEE para assegurar uma melhor coordenação e apoio à acção
} 
Na sua formulação, a Directiva 94/45/CE não encerra, pois, como se viu, qualquer provisão explícita que garanta aos representantes dos trabalhadores o direito de negociar com a direcção central (Carley, 2001) ou de exercer qualquer influência nos processos de decisão (Knudsen, 2003). Em termos formais, a possibilidade de influenciar decisões depende exclusivamente da obrigação, essa sim constituída pela Directiva, para informar e consultar os representantes dos trabalhadores relativamente a um conjunto de questões, contidas no ponto 2 do Anexo à Directiva (como acima expusemos), e que, regra geral, irão constituir-se como as questões que, sendo objecto de informação e consulta em sede dos CEE, se encontram circunscritas pelos acordos.

A possibilidade de influenciar decisões depende, pois, do acesso à informação, da qualidade da informação, da oportunidade da informação, dos modos como é explorada a informação pelos representantes e da conciliação de interesses entre administrações e representantes dos trabalhadores em torno de determinadas questões. Para H. Knudsen (2003: 6) a capacidade de influenciar decisões pode ser definida como a obtenção de determinados resultados ou efeitos que não teriam sido possíveis sem que houvesse uma intervenção no processo de decisão. Para que tal se torne possível, os resultados devem ser favoráveis, simultaneamente, àqueles que influenciam e àqueles que são influenciados. Isto significa que a consulta se efectiva quando a direcção central tem em conta as propostas dos representantes e modifica as suas decisões incorporando essas propostas através da negociação e o estabelecimento de acordos formais ou informais sobre determinadas matérias. ${ }^{13}$

À imagem do que acontece na generalidade dos $\mathrm{CEE}^{14}$, também os CEE onde participam representantes portugueses continuam a pautar-se pelo

\footnotetext{
dos representantes dos trabalhadores; a garantia do acesso à formação tanto em línguas como em matérias mais técnicas, de modo a melhorar a participação dos representantes; a possibilidade de os representantes dos trabalhadores transitarem entre todas as sucursais da multinacional; o estabelecimento de sanções para os casos de desrespeito do estabelecido na Directiva e a possibilidade de os CEE levantarem processos judiciais no caso de incumprimento dos acordos ou dos estabelecido pela Directiva; a clarificação dos termos de renegociação dos acordos; a redução do tempo de negociação dos acordos, cujo limite está actualmente fixado nos três anos após o início do processo; a garantia do recurso a peritos; a possibilidade de os representantes dos trabalhadores acederem a todas as sucursais da multinacional; a garantia de reuniões preparatórias e posteriores às reuniões ordinárias (Costa, 2005: 619-620).

${ }_{13}$ Para uma análise de acordos formais negociados por CEE, cf. Carley (2001); Da Costa e Rehfeldt (2006a, 2006b, 2007).

${ }^{14}$ Num inquérito realizado em 2005 aos representantes em CEE de multinacionais de 196 países (com uma taxa de resposta de 19,8\%), J. Waddington (2005, 2006a, 2006b, 2006c) verificou que apenas $2 \%$ afirmaram que os CEE detêm alguma possibilidade de influenciar decisões já tomadas pelas administrações das multinacionais.
} 
monólogo e pela ineficácia da influência nas decisões. Aos CEE está associado um défice de poder que se traduz numa reduzida capacidade de decisão, acção e reivindicação. Défice que se vê agravado pelo facto de a Directiva não prever quaisquer sanções no caso de as administrações não cumprirem o estipulado nos acordos. ${ }^{15}$

Considerando os três vértices do triângulo, verifica-se, desde logo, que os representantes portugueses são categóricos na afirmação de que só excepcionalmente as informações são transmitidas e discutidas previamente à tomada de decisões, ou seja, atempadamente. O espaço para a consulta, por sua vez, que pressupõe mais do que o intercâmbio de opiniões ou pontos de vista e mais do que a difusão de informações sobre decisões já tomadas de "cima para baixo", revela-se praticamente residual. Finalmente, regra geral, as decisões das administrações já estão tomadas quando são comunicadas aos representantes dos trabalhadores:

Portanto, ou não informa ou informa com prazos que não permitem qualquer acção ou o CEE dá uma parecer, mesmo que seja negativo, que nunca é vinculativo. (Representante dos trabalhadores do CEE da Renault, 18.12.2006)

Antes de mais vou-lhe dizer que a consulta não existe. O que é a consulta de que a Directiva fala? [...] Nós entendemos que é um pedido de opinião prévio à tomada de decisões. [...] Mas isso não acontece. [...] A administração não vai consultar os representantes dos trabalhadores antes de tomar ou adoptar qualquer tipo de estratégia. Eles comunicam-nos factos consumados, estratégias delineadas. [...] O exercício de uma consulta prévia à implementação de uma estratégia deveria ser o ponto fundamental da existência dos comités. (Representante dos trabalhadores do CEE do Grupo Santander, 25.01.2007)

A reduzida capacidade dos CEE para influenciarem decisões - expressão do défice de poder dos CEE - conduz a uma relativização da importância dos CEE e reforça o sentimento de que a luta deve ser acima de tudo conduzida "em casa".

\footnotetext{
${ }^{15}$ Daí a importância do caso da Renault (Vilvoorde, Bélgica, 1997) onde, por intermédio de uma acção judicial interposta pelo CEE, o processo de encerramento da empresa foi interrompido por incumprimento dos deveres de informação e consulta do CEE. O caso Renault revela bem as possibilidades abertas pelos CEE em termos de mobilização. Mobilização dos trabalhadores (euro-greves e euro-manifestações), mas igualmente mobilização jurídica dos CEE como factor impulsionador de um direito do trabalho comunitário (Didry, 2001). A discrepância entre os quadros jurídicos nacionais é, aliás, apontada pelos representantes portugueses como uma das limitações ao funcionamento dos CEE.
} 
Se a administração tomar uma decisão é muito difícil alterá-la. É impossível. São multinacionais, não é?! [...] O CEE não tem qualquer hipótese. Faz pressão mas não passa disso. Quantas multinacionais fecharam em Portugal? Nós aqui tivemos de aceitar as 40 horas ou fechávamos. Houve uma empresa no Reino Unido que não aceitou e fechou. 3.000 pessoas para a rua! [...] A gente mostra o nosso desagrado mas não há força. Há empresas que fecham não por serem inviáveis, mas para enviar um sinal positivo aos accionistas. Fecham por uma questão de estratégia. No nosso caso, foram as 40 horas: ou fazíamos as 40 horas ou fechávamos. A política do Grupo é 40 horas e mais nada! (Representante dos trabalhadores do CEE da Continental Teves, 23.01.2007)

A incapacidade de influenciar decisões é a grande limitação dos CEE. Mas também temos que perceber que nós representamos as abelhas, mas eles é que são os donos da colmeia. Seja de forma mais pacífica ou mais conflituosa, se uma decisão está tomada dificilmente se altera! (Representante dos trabalhadores do CEE da Unisys, 25.01.2007)

O problema é que tínhamos coisas prioritárias, havia problemas mais urgentes dentro da empresa e demos prioridade a essas questões. Partir para um patamar acima sem arrumar a casa primeiro é como começar uma casa a partir do telhado. O que é fundamental é ter uma boa estrutura a nível nacional para poder ir para outro nível. Ir só por ir não interessa. Agora temos uma boa estrutura. Depois, os CEE não resolvem questões específicas de uma empresa, isso cabe às organizações dos trabalhadores locais. Se se tiver uma boa estrutura por detrás de si e se se conhecer muito bem a empresa onde se trabalha é mais fácil apresentar questões pertinentes no CEE. (Representante dos trabalhadores do CEE da Parmalat, 26.01.2007)

Do ponto de vista dos representantes portugueses, as possibilidades práticas dos CEE serão tanto mais perceptíveis quanto mais tornarem possível alcançar resultados palpáveis a nível local. Trata-se, pois, de uma visão pragmática relativamente aos CEE que se explica em virtude das desigualdades de condições socioeconómicas e laborais vividas entre trabalhadores de diferentes países, ainda que da mesma multinacional. Com efeito, na troca de experiências com representantes de diferentes países, é posta em evidência a heterogeneidade de condições de trabalho locais, facto que por si só leva os representantes dos trabalhadores portugueses a percepcionar os CEE como um instrumento através do qual as condições de trabalho podem vir a ser niveladas em seu favor. Stirling e Tully (2004) constataram a tendência para os trabalhadores dos países do Sul da Europa considerarem os CEE como um espaço propício à comparação das diferentes condições de trabalho a nível internacional e, logo, como uma potencial alavanca para 
a melhoria das suas condições a nível nacional. ${ }^{16}$ Os trabalhadores dos países do Norte, por sua vez, beneficiando já de melhores condições laborais, estariam mais bem preparados para aceitar o papel de informação e consulta dos CEE e para uma sua orientação para questões de carácter efectivamente transnacional. Ou seja, estamos diante de percepções distintas e potencialmente conflituantes sobre o papel e objectivos dos CEE e, portanto, mais aptas a provocarem cisões do que a fomentarem a unidade entre colectivos de trabalhadores de diferentes países ainda que da mesma multinacional.

Uma grande parte dos representantes portugueses entrevistados concebe, pois, os CEE como uma via potencial para a resolução de problemas locais, ainda que desconfie da real capacidade dos CEE para resolver tais problemas. Por outro, para os representantes portugueses em CEE a probabilidade de estas estruturas intervirem com sucesso depende fortemente do tipo de problema que está colocado em cima da mesa.

Assim, os CEE aparecem como particularmente eficazes para resolver questões ligadas às condições de trabalho, nomeadamente no tocante à saúde, higiene e segurança no trabalho, já que as questões salariais se encontram arredadas dos tópicos de questões objecto de informação e consulta. Muitas multinacionais arvoram, de facto, a bandeira da segurança, inclusive como componente de uma dimensão de responsabilidade social empresarial (Walters, 2000): ${ }^{17}$

Numa reunião eu levantei determinadas questões que tinham a ver com a segurança e, no intervalo, o vice-presidente da [multinacional] convocou as tradutoras para ter uma reunião comigo. O facto é que a responsável inglesa pela segurança a nível europeu, na última reunião já lá não estava. Com certeza que ele aproveitou os meus dados para contradizer os dados que ela apresentava com uma segurança que não correspondia à realidade! Eu contestei algumas afirmações dela e ele convocou-me logo. Resultou!

ENTREVISTADOR: E a nível local, provocou alterações?

ENTREVISTADO: $\mathrm{Na}$ fábrica teve.

\footnotetext{
${ }_{16}$ Análises sobre os principais obstáculos à constituição de CEE em multinacionais com sede em Portugal mostram que as prioridades nacionais secundarizam a constituição de CEE. Confrontados com diversos problemas nacionais e locais, a constituição de CEE é relegada para segundo plano. A defesa dos trabalhadores a nível da empresa estabelece-se, de resto, como uma prioridade (Costa e Araújo, 2006, 2007a, 2008).

${ }_{17}$ Em todo o caso, segundo Vogel (2005: 73), tais empresas consideram ser do seu interesse agir mais responsavelmente, não tanto para se distinguirem das suas concorrentes, mas, precisamente, para evitarem ser distinguidas. Pelo menos inicialmente, o seu objectivo principal não era utilizar a responsabilidade social empresarial como fonte de vantagem competitiva, mas antes evitar que essa se assumisse como uma fonte de desvantagem competitiva.
} 
ENTREVISTADOR: De algum modo, os CEE permitem tocar num patamar de decisão ao qual não se chegaria?

ENTREVISTADO: A minha intenção é sempre melhorar as condições dos trabalhadores e, claro, eles só aproveitam aquilo que quiserem das minhas intervenções. Para eles, a higiene e segurança é fundamental. (Representantes dos trabalhadores do CEE da Tate \& Lyle)

Porém, a capacidade de intervenção dos CEE decresce substancialmente quando estão em jogo cenários de reestruturações - o que de alguma forma vem contrariar as esperanças depositadas nos CEE e contidas no texto da Directiva $^{18}-$, assim como decresce quando se trata de enfrentar as grandes questões, que são sempre questões locais:

As pessoas estão conscientes que este organismo não está a discutir salários, não está a discutir nada que lhes traga dinheiro, que lhes traga um poder de compra maior. As pessoas estão elucidadas sobre isso mas a pergunta mantém-se: "o que é que isso vai trazer de bom para nós?”. (Representante dos trabalhadores do CEE da Transdev, 04.12.2006)

Quando o senhor me estava lá a mostrar os gráficos e aqueles números todos, aquilo não me interessava para nada. Eu queria era saber das condições de trabalho dos trabalhadores em Portugal. Salários, direitos, tudo isso! (Representante dos trabalhadores do CEE da Honeywell, 11.01.2007)

Em resumo, a importância dos CEE deriva grandemente, por um lado, do facto de permitirem aos representantes portugueses terem acesso a um patamar de decisão superior, constituindo os CEE espaços privilegiados de auxílio à resolução de problemas locais. Por outro lado, ainda na mesma linha, por permitirem aos trabalhadores portugueses terem conhecimento e, eventualmente, acesso a um conjunto de direitos e benefícios. Uma atitude instrumental e limitada que se encontra no cerne do debate que vem animando a literatura actual sobre $\mathrm{CEE}$ e que poderíamos resumir à seguinte constatação: a capacidade de acção dos CEE encontra-se fortemente ligada

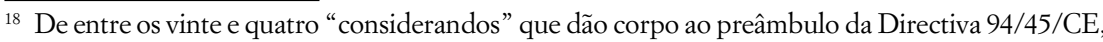
será porventura o nono aquele que melhor sistematiza as razões de fundo desta lei comunitária: "Considerando que o funcionamento de mercado interno implica um processo de concentrações de empresas, fusões transfronteiriças, absorções e associações e, consequentemente, uma transnacionalização das empresas e dos grupos de empresas; que, para assegurar o desenvolvimento harmonioso das actividades económicas, é necessário que as empresas e os grupos de empresas que operam em diversos Estados-membros informem e consultem os representantes dos trabalhadores afectados pelas suas decisões”.
} 
ao desenvolvimento de uma identidade colectiva. Perante esta constatação, a atenção tem-se centrado nos factores que limitam ou aumentam as possibilidades de os CEE forjarem essa identidade colectiva.

\section{Os Conselhos de Empresa Europeus em busca de (outros) Conselhos de Empresa Europeus?}

O cenário pouco optimista sugerido pela opinião dos representantes de trabalhadores portugueses relativamente às duas dimensões dos CEE anteriormente expostas - a da funcionalidade e a das possibilidades práticas (que faz com que, outrossim, soem respectivamente a disfuncionalidades e a impossibilidades) -, não impede, todavia, a identificação de "dinâmicas produtivas" propiciadas pelos CEE. A este respeito, damos conta do modo como, através dos CEE, é possível praticar um valor essencial para a edificação da uma identidade laboral além-fronteiras: a solidariedade transnacional. Adiante adoptaremos como referência o caso da Opel da Azambuja, onde cooperação e solidariedade se materializaram numa posição de força assumida por um todo - o CEE -, com o intuito de contrariar a estratégia de enfraquecimento das partes - as sucursais - empreendida pela administração da General Motors (GM-Europa).

Recorde-se, aliás, que uma das expectativas que animou a emergência da Directiva sobre os CEE residiu nas potencialidades que estas instituições poderiam vir a desempenhar enquanto indutoras de acções de cooperação e solidariedade transnacionais. Perspectivava-se a possibilidade de os CEE virem a agir como um actor colectivo, ao invés de agirem de forma individual e fragmentada. Ora, agindo como actor colectivo, os CEE mostrar-se-iam capazes de desenvolver uma identidade comum, agregando interesses trasnacionais e orientado-se para resultados igualmente transnacionais. Tratar-se-ia, neste caso, de CEE de tipo participativo (Lecher et al., 1999) ou eurocêntrico (Bicknell, 2007). Porém, agindo de forma individualizada/fragmentada e, portanto, tolerando a competitividade entre sucursais como nota dominante (Hancké, 2000; Knudsen, 2003; Bicknell, 2007), estaríamos diante de CEE de tipo prestador de serviços (service providers) ou orientados para projectos (project-oriented), na acepção de W. Lecher et al. (1999).

Nas entrevistas com os representantes dos trabalhadores portugueses, é notório que a conjuntura económica ${ }^{19}$ e a competitividade entre sucur-

${ }_{19}$ Uma conjuntura económica favorável é, aliás, um dos factores considerados fundamentais pelos representantes portugueses para poder dar cumprimento aos objectivos estipulados pela Directiva e dinamizar o funcionamento dos CEE (Vide Quadro-síntese em anexo). 
sais são elementos impeditivos do desenvolvimento da coesão e cooperação no seio dos CEE. Daí que a solidariedade, quando posta em prática, assuma por vezes os contornos de uma solidariedade forçada na medida em que quem a pratica está consciente de que o que acontece numa sucursal pode vir a repercutir-se negativamente nas restantes. É, pois, uma vez mais, a defesa de interesses locais que condiciona as possíveis acções solidárias transnacionais dos representantes. E, aliás, é a participação nos CEE que melhor permite compreender a extensão dos problemas com que se confrontam as multinacionais e antever possíveis embates no plano local:

Aquilo é um CEE mas cada um sabe de si, cada um trata de si! Se aparece um determinado problema mandam-nos resolvê-lo a nível local. [...] Hoje há muita concorrência e essa começa logo dentro do mesmo Grupo. [...] Há uma questão que é aqui fundamental: é a questão do emprego. E, para se preservar os empregos, não pode haver solidariedade. E eles sabem isso! (Representante dos trabalhadores do CEE da Honeywell, 11.01.2007)

Por que razão um país que não tem um dado problemas se vai solidarizar com outros que o têm? Só se for uma coisa que afecte grandemente toda a gente. Se for um problema que afecte um único país não há grande possibilidade de criar qualquer tipo de solidariedade. Se há um problema num único país é esse país que tem de o resolver. (Representante dos trabalhadores do CEE da Unisys, 25.01.2007)

A grande vantagem é permitir que eu tenha acesso a alguns problemas que ainda não nos afectam mas que podem vir a afectar. As experiências dos outros são importantes. O CEE serve para eu saber antecipadamente alguns dos problemas com os quais me poderei vir a confrontar e quais as formas de os resolver. (Representante dos trabalhadores do CEE da Continental, 23.01.2007)

A solidariedade transnacional aparece, assim, no discurso dos representantes simultaneamente como uma vantagem (porventura mais imaginada do que real) e como uma limitação (porventura mais real do que imaginada). A nosso ver, é nos momentos em que é "posto à prova" que um dado CEE terá oportunidade de medir a sua coesão e a sua capacidade de cooperação. E, no contexto das empresas multinacionais, ser posto à prova pode significar, para uns, reestruturações, perdas de produção, desinvestimentos, despedimentos colectivos, mas igualmente, para outros, ganhos de produção e de postos de trabalho, a garantia da permanência da empresa num local específico por um tempo indefinido. A incerteza passou a ser parte 
integrante da forma como as sucursais das multinacionais olham para si mesmas. A desconfiança passou a ser parte integrante da forma como as sucursais das multinacionais se olham entre si. ${ }^{20}$

O caso da Opel de Azambuja foi, por isso, revelador do modo como, ante uma "morte anunciada", o CEE da GM-Europa (constituído em 1996 por iniciativa do sindicato metalúrgico alemão IG-Metall) tornou possível a coesão, cooperação e solidariedade entre os trabalhadores do Grupo GM-Europa, superando assim (mesmo que apenas momentaneamente, em Junho e Julho de 2006) as diferenças entre representantes dos trabalhadores e as clivagens entre representações nacionais.

Muito se disse sobre o encerramento da sucursal da GM na Azambuja, consumado em Dezembro de 2006. Já em Maio de 2006, um documento da GM divulgado na imprensa portuguesa colocava o futuro da fábrica portuguesa numa situação de grande incerteza, ao afirmar que a produção de cada Opel Combo produzido pela fábrica da Azambuja era cerca de 500 dólares (430 euros) mais cara do que em outras fábricas do grupo não especificadas. As estruturas representativas dos trabalhadores da GM Portugal e GM Europa classificaram o documento de "pouco sério" e "superficial". Mas tratou-se de um documento que foi levado a sério pela administração e que, como oportunamente titulavam alguns jornais, colocava frente a frente David contra Golias. O nosso propósito aqui é tão-só o de recuperar a posição e a experiência do então representante dos trabalhadores no CEE da $\mathrm{GM}^{21}$, para, por um lado, realçar que os CEE não podem ser considerados como instituições naturalmente solidárias (Stirling e Tully, 2004: 86) e, por outro lado, tentar compreender quais as condições necessárias para que os CEE ultrapassem as suas fracturas internas e respondam aos desafios como um actor colectivo com voz própria.

Para o ex-representante dos trabalhadores, a unidade do CEE foi crescendo à medida que foi crescendo a instabilidade interna do Grupo GM e se foi tornando manifesta a vulnerabilidade das sucursais europeias. O que se tornou evidente aos olhos dos representantes dos trabalhadores foi que, para minimizar os efeitos dos desinvestimentos da GM na Europa, iria ser necessário desenvolver uma estratégia de reacção baseada na solidariedade e na cooperação como únicas formas de contrariar a abordagem pela com-

\footnotetext{
${ }^{20}$ As administrações das multinacionais foram, de resto, céleres a compreender as possibilidades de um fórum onde se podem tornar patentes as diferenças (de produtividade e de competitividade) como forma de incrementar a competição entre sucursais (Weston e Martinez Lucio, 1997).

${ }_{21}$ À data em que foi entrevistado (Novembro de 2006), o representante português dos trabalhadores da GM contava oito anos de experiência na condição de membro efectivo do CEE. Foi indicado como representante pela comissão de trabalhadores, ao passo que o seu suplente (igualmente presente no momento da entrevista) havia sido indicado pelo sindicato dos metalúrgicos.
} 
petição entre sucursais adoptada pela GM. Tarefa que se revelou titânica para este pequeno David, na medida em que é sempre difícil fazer com que "as pessoas se mobilizem para defender o posto de trabalho de outrem" (Representante dos trabalhadores do CEE da GM, 27.11.2006). Unificar interesses divergentes e potencialmente conflituantes com base na solidariedade representou, por isso, só por si, uma vitória significativa. Com efeito, a divulgação da situação de vulnerabilidade vivida na Azambuja ao conjunto das sucursais da multinacional e o conflito entre duas partes claramente identificáveis serviram, pois, de base para criar um esprit de corps sem precedentes no seio do CEE da GM.

A unidade só foi possível porque os representantes dos trabalhadores se mobilizaram e actuaram em diferentes escalas (europeia, nacional e local), com base num objectivo comum, numa relação de confiança (Bartmann e Blum-Geenen, 2006) e dispondo de um importante suporte sindical europeu. ${ }^{22} \mathrm{Na}$ verdade, o CEE da GM-Europa constituiu um importante dinamizador da mobilização colectiva transnacional, pois várias fábricas pararam noutros países em Junho e Julho de 2006, realizando acções de solidariedade em favor dos trabalhadores da Azambuja. Com efeito, teve lugar uma grande campanha de informação que culminou em várias acções de solidariedade: na Suécia os trabalhadores pararam 2 horas por cada turno e na Alemanha foi accionado um fundo de greve em favor dos trabalhadores portugueses:

Tudo foi precedido de uma grande estratégia de informação, semanal [...] sobre o que é que o fórum [CEE, ou European Employee Forum, com é conhecido o CEE da GM-Europa] estava a fazer, sobre o que é que os sindicatos estavam a fazer... [...] O fórum reuniu-se com os representantes dos trabalhadores na Azambuja, foi lá ver e tal e não sei quê. [...] Inclusive num dos plenários houve um colega meu alemão que me pediu para eu enviar por e-mail uma fotografia minha que ele iria pôr lá, projectar, para dizer que este é o homem que está em Portugal a lutar pelo não encerramento da fábrica, para as pessoas sentirem maior proximidade. E deu resul-

\footnotetext{
${ }^{22}$ Realce-se, com efeito, a importância da interface entre o CEE e o Grupo de Coordenação Sindical da GM-Europa (que contou com a participação da Federação Europeia dos Metalúrgicos). Foi no âmbito desse grupo de coordenação sindical (e mesmo antes do CEE) que o problema do encerramento da fábrica portuguesa primeiramente se discutiu. Pode mesmo dizer-se que o grupo de coordenação sindical liderou a revolta, tendo sido de imediato secundado pelo CEE nessa missão. Este ponto deve ser aqui enfatizado como um ponto decisivo para o funcionamento dos CEE, uma vez que a possibilidade de se dispor de um suporte sindical (ou mesmo de comissões de trabalhadores) na retaguarda da actuação dos representantes em CEE ajuda a transpor para o CEE, além de conhecimento da situação sócio-laboral de uma determinada empresa ou sector, "lições" de combatividade, negociação e organização que podem ser úteis na maximização de uma acção solidária transnacional (Costa e Araújo, 2007c: 208).
} 
tado, deu resultado. [...] Como sabem, os alemães e belgas, creio, alguns sindicatos na Europa têm por cultura terem um fundo de luta, um fundo de greve. Nós não temos, mas eles têm. Fazem dois, três dias de greve e recebem, por exemplo, o equivalente a um dia. Não perdem tudo. [...] Deu resultado, eles mandaram dinheiro, juntaram trabalhadores de todas as fábricas, pediram aos sindicatos para explicarem às pessoas, recolheram e deu resultado. Mandaram, não foi muito, mas mandaram... Juntámos ainda uns milhares de euros que depois dissemos às pessoas para virem levantar, mediante a apresentação do recibo com as horas de greve perdidas. Portanto, isso deu resultado porque mobilizou as pessoas também, saberem que alguém que não as conhecia de lado nenhum estava a contribuir, nem que fosse com um euro. [...]. Portanto, isto tudo mobilizou. Quer dizer, agora, se a importância do CEE não pode ser reconhecida ou não deve ser reconhecida através dessas acções, então digam-me o que é que pode. Então digam-me o que é que pode? (Representante dos trabalhadores no CEE da GM-Europa, 27.11.2006)

No final, é certo que foi sem grandes surpresas que Golias (a GM) ganhou a batalha, se é que se pode falar em vencedores e vencidos quando existem vidas reais por detrás dos números. $\mathrm{Na}$ Azambuja, perderam-se mais de 1.000 postos de trabalho e multinacional deslocalizou a sua produção para Saragoça. Talvez por isso, e tendo em conta este desfecho, grande parte dos representantes portugueses de outros CEE que entrevistámos tenda a ver no "caso Opel da Azambuja” um sinal claro de défice de poder e de ineficácia dos CEE. Mesmo não tendo grandes ilusões quando à resposta que a GM poderia ter dado às pretensões dos trabalhadores, o representante português do CEE da GM-Europa considera que os trabalhadores da fábrica portuguesa foram traídos pela empresa, mas sem nunca pôr em causa o CEE e a dinâmica de solidariedade que (como acima se mostrou) aquele ajudou a criar:

Não é a fábrica da Azambuja que tem 1.100 trabalhadores que vai contrariar uma decisão que já esteja tomada [...]. O que eles pagaram aqui pagam a 300 trabalhadores na Alemanha para se irem embora... a 300... a um terço... Eles ganham três vezes mais que nós. Então o que é que custa limpar uma fábrica destas? [...].

As pessoas ficaram defraudadas com a empresa, porque assinou um acordo social com os trabalhadores o ano passado [2005], por três anos, que garantia a continuidade [da fábrica] até 2009. Chega um ano depois e corta. [Os trabalhadores] ficaram defraudados com a GM, sentiram-se enganados, traídos pela GM. Pela GM! Nunca puseram em causa a seriedade nem o envolvimento correcto e honesto dos representantes dos trabalhadores. (Representante dos trabalhadores do CEE da GM-Europa, 27.11.2006) 
A partir do caso da Opel da Azambuja, que ilações se podem retirar? Para além da óbvia lição de solidariedade transnacional, inclusive demonstrada pelos principais "beneficiários" da deslocalização - os trabalhadores espanhóis de Saragoça $a^{23}$-, o que se tornou claro é que a composição, o funcionamento e as práticas de um CEE não podem ser percepcionados como estando definidos de uma vez por todas. Haverá, no decorrer da vida dos CEE, situações susceptíveis de conduzir a uma maior ou menor confluência no entendimento, entre os actores que participam directa ou indirectamente nos CEE, daquilo que são os seus princípios orientadores, os seus objectivos e as acções a desenvolver para lhes dar corpo. Só um contínuo acompanhamento do CEE da GM permitiria, porém, verificar se essa confluência de interesses despoletada por uma situação de crise se manteria em períodos de acalmia.

Significa isto que a vida dos CEE não é feita exclusivamente dessas "provas de fogo" decisivas. Aquilo que se designa por identidade colectiva dos CEE assentaria, afinal, na estabilidade dessa coesão interna e dessa perspectiva comum que deriva e se encontra comprometida com a defesa dos interesses da força de trabalho como um todo e não de interesses nacionais selectivos.

A análise empírica sobre a experiência dos representantes portugueses revelou, todavia, que estes transportam consigo inquietações e agendas que, porque de foro local, os distanciam do ideal transnacional e altruísta descrito acima. A possibilidade de os representantes portugueses se projectarem no plano transnacional encontra-se ainda fortemente condicionada pela necessidade que efectivamente demonstram de ver consolidada a sua posição no plano nacional/local.

$\mathrm{Na}$ generalidade dos casos, o envolvimento e investimento dos representantes portugueses nos CEE é ainda superficial e causa pouco impacto junto das administrações locais das multinacionais..$^{24}$ Os próprios representantes

\footnotetext{
23 "A seguir à paragem deles, senti o orgulho que eles sentiam de terem conseguido parar a produção cerca de noventa por cento. [...]. Viu-se que não era fingido, que era um orgulho puro, de terem participado e de terem obtido aquele resultado." (Representante dos trabalhadores no CEE da GM-Europa, 27.11.2006).

${ }^{24}$ No âmbito da investigação que serviu de suporte a este artigo foi ainda aplicado um inquérito com o objectivo de apurar as perspectivas e atitudes dos representantes das administrações locais relativamente aos CEE. O inquérito foi realizado por via postal, tendo sido efectuados três envios (Março, Abril e Maio de 2007), e incidiu nas multinacionais nas quais foram identificados representantes dos trabalhadores portugueses. O inquérito foi aplicado em 139 multinacionais, das quais 30 responderam $(21,6 \%)$. Em termos globais, os representantes das administrações locais olham para os CEE de forma relativamente neutra, ou seja, embora reconheçam a sua importância, são unânimes em considerar que estes não têm impactos, positivos ou negativos, significativos na vida das empresas. O efeito positivo mais saliente prende-se com uma maior visibilidade dos problemas locais que, apesar disso, não se traduz, nem na sua resolução, nem na aquisição de quaisquer benefícios pelas empresas locais.
} 
são os primeiros a reconhecer que as suas sucursais não se confrontaram ainda com situações que permitissem avaliar cabalmente as potencialidades e o poder efectivo dos respectivos CEE para agirem com um todo. A sua participação nos CEE é, pois, mais orientada por objectivos de tipo circunscrito do que transnacionais. O que se justifica, de resto, pelas desigualdades entre sucursais (essencialmente no relativo às condições de trabalho) que os CEE acabam por tornar mais visíveis.

Os representantes portugueses estão ainda a aprender a agir de forma transnacional (Costa, 2004, 2006; Costa e Araújo, 2006). ${ }^{25}$ A consolidação das condições subjacentes à sua participação - que vão desde a formação dos representantes até aos apoios das estruturas de representação dos trabalhadores locais e nacionais - representa um passo importante na consolidação da sua participação nos CEE. A percepção dos CEE como um todo implica, pois, que se atenda às condições de participação das partes. Afinal, as expectativas depositadas nos CEE só se poderão cumprir-se se, também nesse aspecto, houver uma confluência entre os actores.

\section{Conclusão}

Os CEE enfrentam, para além das suas próprias tensões internas, desafios consideráveis à sua intervenção como actor colectivo em busca de identidade e de legitimidade (Béthoux, 2004). Os défices, ainda vincados, na concretização da dimensão funcional dos CEE e os avanços, ainda frágeis, na concretização das suas possibilidades práticas recomendam, pois, alguma prudência nas expectativas que se depositam nos CEE. Por idênticas razões, tratando-se de instituições ainda relativamente jovens e em expansão - tanto em número quanto em experiência -, seria apressado pressagiar para os CEE um destino triunfante ou um fracasso retumbante. Parafraseando H. Kotthoff (2007: 178), os pioneiros são viandantes em transição. O que faz do futuro dos CEE algo de relativamente incerto e, portanto, em aberto.

Em termos globais, três linhas de força parecem emergir da avaliação que os representantes portugueses em CEE fazem da eficiência e da eficácia destas instâncias transnacionais. Em primeiro lugar, ainda que sejam organismos orientados pela valorização e para o incremento da participação laboral, na óptica dos representantes portugueses os CEE não detêm poder

\footnotetext{
${ }^{25}$ Holm-Detlev Köhler e Sérgio González Begega (2007) descrevem um tipo de participação dos representantes espanhóis muito semelhante à participação portuguesa. Facto que não deixa de ser surpreendente, já que os representantes portugueses recorrem frequentemente à participação espanhola para destacar o seu profissionalismo em relação ao amadorismo da participação portuguesa.
} 
suficiente para equilibrar as relações de força no seio das multinacionais. Não surpreende, pois, que a aquisição de um maior poder de decisão e de intervenção por parte dos CEE apareça como uma das dimensões reivindicadas pelos representantes portugueses para melhorar o desempenho dos CEE (Costa e Araújo, 2007c: 199). Em segundo lugar, e em decorrência do ponto anterior, é reconhecido um défice de resultados práticos aos CEE. Por exemplo, sempre que uma filial de uma multinacional enfrenta problemas graves (reestruturações, deslocalizações, encerramentos, etc.) sem que os colectivos de trabalhadores consigam inverter o sentido das decisões tomadas pelas administrações reforça-se o sentimento de ineficácia dos CEE. Em terceiro lugar, porém, a relativa desvalorização dos efeitos práticos do CEE não impede a identificação de aspectos positivos (ou de dinâmicas produtivas). Mencionámos aqui a questão da solidariedade transnacional, ainda que os representantes portugueses reconheçam nos CEE outras potencialidades: conferir aos representantes de trabalhadores maiores possibilidades de interlocução e poder frente às administrações locais; permitir às administrações centrais a aquisição de um maior conhecimento da amplitude dos problemas dos trabalhadores das diferentes filiais; uniformizar os sistemas de comparação entre filiais - pois "só havendo valores reais sobre as coisas é que podemos saber se somos mais ou menos produtivos do que os outros" (Representante dos trabalhadores no CEE da Solvay, 22.01.2007) -, tornando assim mais realistas as distinções e mais sustentadas as reivindicações; aceder a um patamar de decisão superior, exercendo assim formas de pressão secundárias, isto é, complementares aos mecanismos nacionais. Assim sendo, é nestas dinâmicas produtivas que, a nosso ver, os trabalhadores devem apoiar-se no futuro pois é dessas possibilidades que dependerá a eficácia futura dos CEE.

Fundamental que foi para impulsionar a informação e consulta dos trabalhadores nas empresas de dimensão comunitária, a Directiva 94/45/CE não pode ser considerada como um produto acabado. Quase uma década passada sobre o timing oportuno para a sua reformulação (1999), só agora se vislumbram sinais que apontam para a sua efectiva revisão. Com efeito, foi com entusiasmo que em Novembro de 2007 o Comité de Direcção da maior estrutura sindical europeia - a Confederação Europeia de Sindicatos (CES) - saudou o facto de a Comissão Europeia, na sequência do debate no Parlamento Europeu sobre programa de trabalho legislativo para 2008, ter confirmado publicamente (na pessoa do seu presidente) a intenção de apresentar propostas de emendas à Directiva de modo a permitir que os CEE possam conhecer antecipadamente e acompanhar os processos de reestruturação empresarial (http://www.etuc.org/a/4305). 
Informação e consulta nas multinacionais | 29

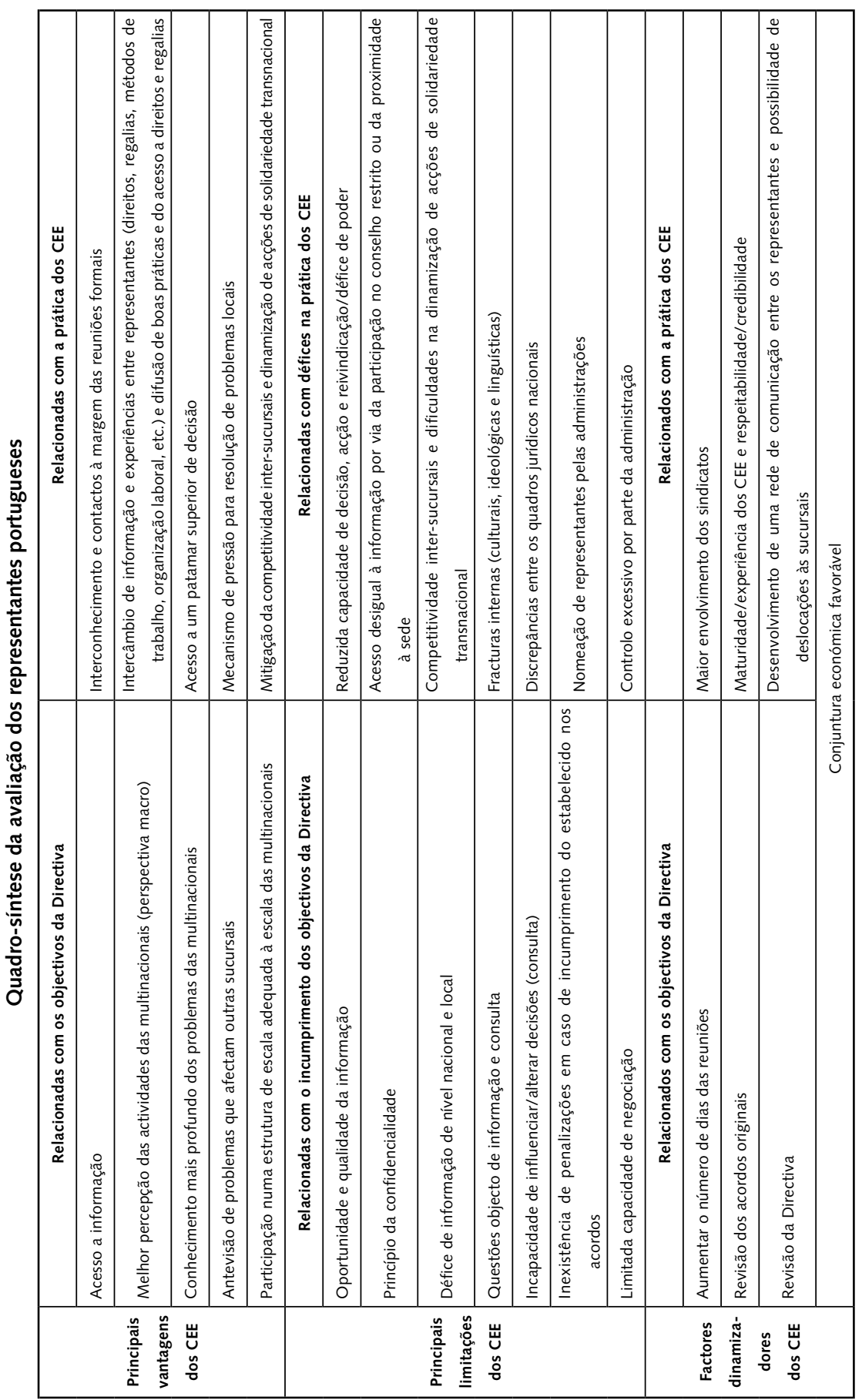


Entretanto, em Portugal, e enquanto o anunciado novo enquadramento jurídico europeu não vê a luz do dia, é fundamental que as principais estruturas sindicais e de representação dos trabalhadores assumam mais convictamente o "projecto CEE", em nome de um reforço do processo de aprendizagem que uma grande parte dos representantes portugueses em CEE ainda atravessa. Valorizar estas instituições de representação transnacional de trabalhadores é, pois, contribuir para valorizar uma identidade laboral no reino das multinacionais.

\section{Referências bibliográficas}

Bartmann, Martin; Blum-Geenen, Sabine (2006), "The Challenge of the 'Solidarity Pledge", Mitbestimmung. International Edition. Disponível em: http://www.boeckler. de/cps/rde/xchg/SID-3D0AB75D-E8D32B96/hbs/hs.xsl/164_83396.html. Acedido em 22.09.2007.

Béthoux, Élodie (2004), "Les Comités d'Entreprises Européens en quête de légitimité", Travail et Emploi, 98, 21-35.

Bicknell, Helen (2007), "Ethno-, Poly- and Eurocentric European Works Councils", in Michael Whittall et al. (orgs.), Towards a European Labour Identity. The Case of the European Works Councils. London: Routledge, 111-131.

Buschak, Willy (1995), "European Works Councils Open New Horizons", Transfer European Review of Labour and Research, 1(1), 133-135.

Carley, Mark (2001), Bargaining at European Level? Joint Texts Negotiated by European Works Councils. Luxembourg: European Foundation for the Improvement of Living and Working Conditions.

Carley, Mark; Marginson, Paul (2000), Comités d'Entreprises Européens. Une étude comparative entre les accords visés à l'article 6 et á l'article 13. Rapport pour la Fondation Européenne pour l'Amélioration des Conditions de Vie et de Travail et la Commission Européenne. Luxembourg: Office des Publications Officielles des Communautés Européennes.

Costa, Hermes Augusto (2004), "O sindicalismo português face aos Conselhos de Empresa Europeus", in B. S. Santos (org.), Trabalhar o mundo: os caminhos do novo internacionalismo operário. Porto: Afrontamento, 173-206.

Costa, Hermes Augusto (2005), Sindicalismo global ou metáfora adiada? Os discursos e as práticas transnacionais da CGTP e da CUT. Coimbra: Faculdade de Economia (diss. de doutoramento).

Costa, Hermes Augusto (2006), "Portuguese Trade Unionism vis-à-vis the European Works Councils", in B. S. Santos; J. A. Nunes (orgs.), Reinventing Democracy: Grassroots Movements in Portugal. London: Routledge, 218-252. 
Costa, Hermes Augusto; Araújo, Pedro (2006), "European Works Councils in Portugal”, European Works Councils Bulletin, 66, 15-18.

Costa, Hermes Augusto; Araújo, Pedro (2007a), "Diálogo social transnacional em multinacionais com sede em Portugal: Conselhos de Empresa Europeus, obstáculos e realizações", Sociedade e Trabalbo, 31, 17-32.

Costa, Hermes Augusto; Araújo, Pedro (2007b), "Os acordos de Conselhos de Empresa Europeus envolvendo representantes de trabalhadores portugueses”, Oficina do CES, 267. Disponível em http://www.ces.uc.pt.

Costa, Hermes Augusto; Araújo, Pedro (2007c), Os Conselhos de Empresa Europeus: Entre a responsabilidade social da empresa e a participação laboral. Relatório Final de Projecto de Investigação Financiado pela Fundação para a Ciência a Tecnologia (POCI/SOC/59689/2004). Coimbra: Centro de Estudos Sociais.

Costa, Hermes Augusto; Araújo, Pedro (2008), "Why European Works Councils Fail to Be Established - the Case of Portugal”, European Journal of Industrial Relations, 14(4) (no prelo).

Da Costa, Isabel; Rehfeldt, Udo (2006a), "European Unions and American Automobile Firms; From European Works Councils to World Councils?”, Labor and Employment Relations Association, Proceedings of the 58th Annual Meeting, January, 5-8, 2006, Boston.

Da Costa, Isabel; Rehfeldt, Udo (2006b), "La négociation collective transnationale européenne chez Ford et General Motors”, Connaissance de L'emploi, 35, 1-4.

Da Costa, Isabel; Rehfledt, Udo (2007), "European Works Councils and Transnational Bargaining about Restructuring in the Auto Industry", Transfer-European Review of Labour and Research, 13(2), 313-316.

Didry, Claude (2001), "Le comité d'entreprise européen devant la justice: mobilisation du droit et travail juridique communautaire", Droit et Société, 49, 911-934.

Didry, Claude; Béthoux, Élodie; Mias, Arnaud (2005), "La construction et les enjeux d'un système de relations professionnelles européen”, in Groupe de Projet Thomas (orgs.), L'Europe et le dialogue social. Recueil de notes, 12, 29-44.

EIRR (2004), "Commission Issues Consultation on EWCs Directive”, European Industrial Relations Review, 365, June, 13-16.

Gilman, Mark; Marginson (2004), “Negotiating European Works Councils. Contours of Constrained Choice", in Ian Fitzgerald; John Stirling (orgs.), European Works Councils. Pessimism of the Intellect, Optimism of the Will?. London: Routledge, 93-112.

Hancké, Bob (2000), "European Works Councils and Industrial Restructuring in the European Motor Industry”, European Journal of Industrial Relations, 6(1), 35-59. Hyman, Richard (2000), "Editorial”, European Journal of Industrial Relations, 6(1), 5-7. Jornal Oficial das Comunidades Europeias (1994), Directiva 94/45/CE do Conselho de 22.09.1994. JOC n. ${ }^{\circ}$ L 254/64, de 30 de Setembro de 1994. 
Kerckhofs, Peter (2003), "Enlargement and European Works Councils”, Transfer-European Review of Labour and Research, 9(1), 162-169.

Kerckhofs, Peter (2006), European Works Councils - Facts and Figures. Brussels: European Trade Union Institute for Research, Education and Health and Safety.

Kerckhofs, Peter; Pas, Irmgard (2004), European Works Councils Database - 2004. Brussels: European Trade Union Institute.

Kerckhofs, Peter; Pas, Irmgard (2006), European Works Councils Database - 2006. Brussels: European Trade Union Institute for Research, Education, Health and Safety

Knudsen, Herman (2003), "European Works Councils - A Way to Employee Influence in Multinational Companies?”, Paper to the 6th. ESA Conference, Murcia, 23-25 September 2003.

Köhler, Holm-Detlev; González Begega, Sérgio (2007), “Still Learning from Europe. Spanish Participation in European Works Councils”, in Michael Whittall et al. (orgs.), Towards a European Labour Identity. The Case of European Works Councils. London: Routledge, 132-149.

Kotthof, Hermann (2007), "The European Works Councils and the Feeling of Interdependence", in Michael Whittall et al. (orgs.), Towards a European Labour Identity. The Case of the European Works Councils. London: Routledge, 169-181.

Lecher, Wolfgang et al. (1999), The Establishment of European Works Councils. From Information Committee to Social Actor. Aldershot: Ashgate.

Leite, Jorge et al. (1996), Conselhos de Empresa Europeus: Comentários à Directiva 94/45/CE. Lisboa: Cosmos.

Marginson, Paul et al. (1998), Negotiating European Works Councils: An Analysis of Agreements under Article 13. Report for the European Foundation for the Improvement of Living and Working Conditions and the European Commission. Luxemburg: Office for Official Publications of the European Communities.

Marx, Karl; Engels, Friedrich (1982), "Manifesto do Partido Comunista”, in J. Barata-Moura et al. (orgs.), Marx e Engels: Obras escolbidas em três tomos (tomo I). Lisboa: Edições "Avante”, 106-136.

Paternotre, Michel (1998), “La Directive ‘Comité d’Entreprise Européen'. État des lieux avant révision”, Observatoire Social Européen, Working Paper, 21. Disponível em: http://www.ose.be/old/fr/publications/detail.htm. Acedido em 7.10.2005.

Stirling, John; Tully, Barbara (2004), "Power, Process, and Practice: Communications in European Works Councils”, European Journal of Industrial Relations, 10(1), 73-89.

Telljohann, Volker (2005), "The European Works Councils — A Role beyond the EC Directive?”, Transfer - European Review of Labour and Research, 1(5), 81-96.

Vogel, David (2005), The Market for Virtue. The Potential and Limits of Corporate Social Responsibility. Washington: Brookings Institutional Press. 
Waddington, Jeremy (2003), "What Do Representatives Think of the Practices of European Works Councils? Views from Six Countries", European Journal of Industrial Relations, 9(3), 303-325.

Waddington, Jeremy (2005), “The Views of European Works Councils Representatives”, Meeting of the What's the Problem Project, Brussels, November 4, 2005.

Waddington, Jeremy (2006a), "How EWC Members See it", Mitbestimmung. International Edition, 8, 41-44.

Waddington, Jeremy (2006b), "The Views of European Works Councils Representatives”, Co-determination in a Modern Europe: Democratic Workers' Participation or Convergence at Minimal Standards, conferência organizada pela Otto Brenner Stifung, Bratislava, 30 de Maio-1 de Junho.

Waddington, Jeremy (2006c), "The Performance of EWCs 12 Years after the Directive”, European Works Councils Bulletin, 65, 7-11.

Walters, D. (2000), "Employee Representation on Health and Safety and European Works Councils”, Industrial Relations Journal, 31(5), 416-436.

Weston, Syd; Martinez Lucio, Miguel (1997), "Trade Unions, Management and European Works Councils: Opening Pandora's Box?”, The International Journal of Human Resource Management, 8(6), 764-779.

Whittall, Michael; Knudsen, Herman; Huijgen, Fred (orgs.) (2007), Towards a European Labour Identity. The Case of the European Works Councils. London: Routledge. Wills, Jane (2000), "Great Expectations: Three Years in the Life of a European Works Council”, European Journal of Industrial Relations, 6(1), 83-105.

Wills, Jane (2004), "Re-scaling Trade Unions Organizations: Lessons from the European Front Line”, in Ronaldo Munck (org.), Labour and Globalisation. Liverpool: Liverpool University Press, 85-104. 